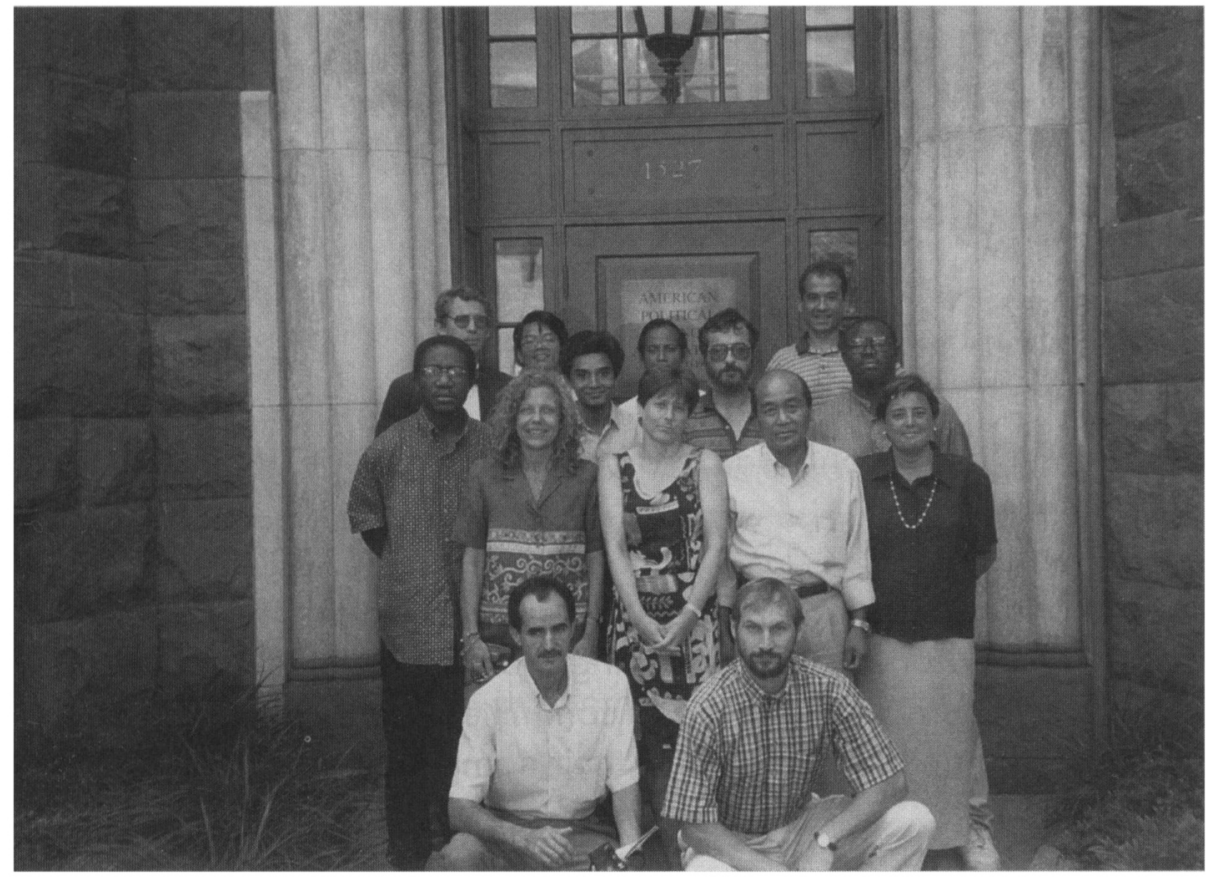

Scholars participating in the USIA-sponsored Summer Institute visit APSA. Back row (L to R): Petr Drulak, Czech Repubic; Phimol Phupipidh, Thailand; Sugiono, Indonesia; Arturo Zárate-Ruiz, Mexico. Third row (L to R): Anatole Ayissi, Cameroon; Amit Dholakia, India; Jovan Donev, Macedonia; Victor Adetula, Nigeria. Second row (L to R): Gladys Lechini, Argentina; Wendy Asbeck-Brusee, The Netherlands; Jitendra Dhoj Khand, Nepal; Caterina Garcia-Lopez, Spain. Front row kneeling (L to R): Hocine Boukara. Algeria; Georgii Maltsev, Russia. Not pictured: Plamen Pantev, Bulgaria; Rodrigo Valderrama, Columbia; Philip Nel, South Africa; Nguyen Yen Huang, Vietnam.

\section{USIA Summer Institute Participants Visit APSA}

Throughout the summer the APSA welcomed several groups of international scholars participating in U.S. Information Agency-sponsored Summer Institutes to the national office. As part of their programs in Washington, D.C., groups from the University of Michigan and Southern Illinois University met with APSA staff members to learn more about the Association and its mission. Led by APSA's Director of Educational Affairs, Sheilah Mann, and joined by Executive Director Catherine Rudder and Deputy Director Robert Hauck, the visiting scholars were briefed on Association activities in the United States and around the world. Discussion topics included the role of the Association in the discipline and enabled a mutual exchange of ideas about civics education and teaching. Members of the visiting groups were also given complimentary APSA memberships to allow them to follow the Association's activities.

What follows are summary articles on each Institute, prepared by Bear F. Braumoeller, University of Michigan, and John L. Foster, Southern Illinois University, respectively.

\section{University of Michigan Summer Institute in American Foreign Policy}

The United States Information Agency (USIA) sponsors a yearly summer program in American foreign policy. For the past two years, the program has been based at the University of Michigan.

The participants, who range in experience from lecturers to department heads, represent a wide range of countries-in two years, 32 countries have been represented-and bring with them a diverse array of experiences and perspectives.

Participants meet at the Center for Political Studies at the Institute for Social Research to take part in daily seminars as well as in occasional special events, such as teleconferences and presentations by visiting scholars. The program administrator and Director of CPS, Professor William Zimmerman, de- signs the program content to incorporate insights from the subfields of American politics, comparative politics, and international relations.

In addition to its academic regimen, the program offers social activities, such as a trip to see the (now) world-famous Toledo Mud Hens. Participants also take a field trip to Chicago, where they experience the intellectual life at the University of Chicago and the social life of the city.

The program concludes with one week in Washington, D.C. Among the scholars and policymakers with whom the participants met in Washington were Richard Haass, Director of Foreign Policy Studies at the Brookings Institution, former Assistant Secretary of State Arnold Kanter, Professor James Rosenau of George Washington University, former American Ambassador to Latvia Ints Silins, and Richard Solomon, Director of the United States Institute for Peace.

\section{Summer Institute on the U.S. Political System}

The 1997 USIA Summer Institute in the American Political System, held from June 27 to August 9, 1997 , was the fourth on the campus of Southern Illinois University at Carbondale. Each participant in the 1997 SIUC institute has responsibility for university-level courses on American government, politics and history in their home country, but had little or no previous direct exposure to the United States. Five of the 1997 participants came from Latin American nations, three from Africa, six from Asia, three from the former Soviet Union or Soviet bloc, and one from Western Europe.

The broad goal of this institute-as of the previous three-was to provide the participants with as thorough an immersion in American government, politics, and political culture as possible. The central organizing theme of the 1997 institute was the American federal system with its rather unique division of governmental responsibility across national, state, and local units of government. A secondary theme was to compare and contrast the Ameri- 
can approach to the universal problems of governing with those of other nations. Most of the 1997 participants came from countries which have changed either from singleparty communist or military rule to fledgling democracies within the past decade. The American experience of over 200 years under the same constitutional form of government provides a sharp contrast with their experiences in their homelands.

Throughout the institute we tried to mix contemporary political science scholarship (including the latest teaching materials on American governments) with direct contact with the practitioners of government and politics at all three levels. Most of the faculty in the SIUC Department of Political Science, as well as a number of faculty from other departments in the College of Liberal Arts and School of Law, participated. And this year we were able to add two members of the staff of the new SIU Public Policy Instituteformer U.S. Senator Paul Simon and former Press Secretary to Governor Jim Edgar Mike Lawrence to our program.

Classroom time was supplemented with one week long trip to the Illinois state capital in Springfield and a variety of sites in Chicago and a second one week trip to Washington, D.C.

\section{Harvard University Library and APSA Launch PROceedings}

Selected scholarly papers from the 1997 APSA Annual Meeting are now available on-line through PROceedings: Political Research Online. Currently in a concept demonstration phase, PROceedings will offer the papers free of charge through August 1998. The PROceedings web site is located at

http://PRO.harvard.edu/

The PROceedings project aims to disseminate political science research more broadly and directly, to continue the scholarly exchange of the annual meetings beyond their settings, to encourage the instructional use of recent research, to support the process of peer review for scholarly journals, and to facilitate individual and library access to the annual meeting papers.

Authors from fourteen of the 1997 Annual Meeting's divisions submitted their papers to William J. Ball of The College of New Jersey, the director and primary administrator of the pilot project, who converted the papers to Portable Document Format and placed them on the project web site at Harvard University Library.

PROceedings features research papers from numerous subfields of political science. Papers can be accessed by browsing relevant portions of the annual meeting program or by searching extended abstracts. Users are welcome to view or print the papers, and to use them in ways consistent with the Association's copyright.

PROceedings is a collaborative project of the APSA and Harvard University Library. In addition to Ball the project director other principals involved include Sheilah Mann of the APSA and Sidney Verba and Dale Flecker of the Harvard University Library.

A demonstration of the PROceedings project was featured at the APSA booth during the Association's 1997 Annual Meeting in Washington.

\section{Committee Suggestions Welcomed}

The APSA welcomes suggestions for individuals interested in serving on APSA standing committees for terms beginning January 1, 1999. Appointments vary from one to three years and include award committees, PS Editorial Board, and a host of others. A listing of committees and their area of responsibility can be found in the March 1997 issue of PS. These positions are held on a volunteer basis. Interested members should make their suggestions by mail to President-Elect Matthew Holden, c/o the National Office at 1527 New Hampshire Ave., NW, Washington, DC 20036 or by email to nominations@apsanet.org.

\section{Conference Weighs Adjuncts' Impact}

Six APSA representatives participated in a conference on the use of part-time and adjunct faculty throughout the weekend of September 26 in Washington, D.C. Attendees included David Adamany of Wayne State University, Robert Dudley of George Mason University, Milton Greenberg of American University, Charles Harris of Howard University, Catherine Rudder of APSA, and Toni-Michele Travis of George Mason University.

Initiated by the American Historical Association, the conference was co-sponsored by AHA, APSA, and several other scholarly organizations and the American Association of University Professors. Representatives of these organizations and others offered the perspectives of graduate students, adjunct and part-time professors, full time faculty, administrators, union organizers, and scholars of and leaders in higher education.

Adamany, outgoing President of Wayne State, prepared a paper for the conference to make the case for the value of part-time faculty and served on one of the panels at the meeting. In his presentation he listed a series of characteristics of an industry-such as costs of service consistently exceeding the inflation rate, independence of practitioners, and apparent lack of external accountability-and challenged the audience to identify what enterprise he was referencing. Though higher education was the likely guess, to the contrary, Adamany averred that he was referring to the health care industry. His admonition, consistent with that of several other observers of trends in postsecondary education at the meeting, was that to be complacent was to be complicit in impending changes that could be anathema to academics.

Other speakers lamented the use of part-time faculty as simply a substitute for cheap labor and a way to avoid the tenure system. It was recognized, however, that part-timers can add flexibility, specialized knowledge, and fresh perspectives to an institution. Moreover, full-time faculty often prefer that part-time em- 